\title{
SISTEM INFORMASI MANAJEMEN MENURUT PRESPEKTIF ISLAM
}

\author{
Hamdi Agustin \\ Dosen Fakultas Ekonomi, Universitas Islam Riau (UIR) \\ Email :hamdiagustin@yahoo.com
}

\begin{abstract}
ABSTRAK
Tujuan penelitian ini adalah mengindentifikasi sistem informasi manajemen dalam prespektif Islam. Dalam perspektif Islam terdapat sumber informasi yang selalu digunakan atau dimanfaatkan oleh manusia. Sumber Informasi tersebut terdiri dari wahyu Allah SWT berupa Al-Qur'an dan Al-Hadist yang berasal dari Nabi Muhammad SAW yang merupakan penjelasan dari Al-Qur'an. Banyak pendapat para ahli mengenai pengertian sistem informasi manajemen secara konvensional. Namun berdasarkan prespektif Islam pengertian sistem informasi manajemen adalah proses pengolahan data menjadi suatu informasi yang benar dan jujur berdasarkan Al-Qur'an dan Al-Hadist untuk dapat digunakan dalam membuat keputusan. Terdapat perbedaan sistem informasi manajemen berdasarkan syariah dengan konvensional. Perbedaan ini terutama pada perencanaan dan pengambilan rujukan dan dasar dalam mencari sumber informasi yaitu Al-Quran dan Al-Hadist. Sedangkan sistem informasi manajemen konvensional mencari rujukan pada para ahli dan pakar dibidangnya yang semuanya berdasarkan akal fikiran mereka.
\end{abstract}

\section{Kata kunci : Sistem Informasi Manajemen, Prespektif Islam.}

\begin{abstract}
The purpose of this paper is to identify the management information system in Islamic perspective. In Islamic perspective there is a source of information that always used or utilized by an humans. The source of information consists of revelations from Allah SWT in the form of Al Qur'an and Al-Hadith derived from Prophet Muhammad SAW which is an explanation of the Qur'an. Many opinions from experts understanding management information systems conventionally. But based on the Islamic perspective understanding of management information systems is the process of data processing into true and truthful information based on Al Quran and Al Hadist to be used to make planning and decision making. There are differences between management information system based on sharia and conventional. This distinction is mainly on the reference and foundation in searching for the source of information that is the Quran and Sunnah while conventional management information systems seek referrals to experts and experts in their fields that are all based on their intellect.
\end{abstract}

Keywords : Information Management System, Islamic Perspective. 


\section{PENDAHULUAN}

Sesungguhnya Islam hadir dengan memberikan dan menyediakan informasi. Informasi dari zaman Nabi Adam AS hingga Nabi akhir zaman, Muhammad SAW dikumpulkan menjadi informasi agama Islam. Informasi tersebut meliputi Al-Qur'an, Hadist dan penjelasan serta pendapat ulama mengenai Islam secara keseluruhan. Dalam perspektif Islam terdapat sumber informasi yang selalu digunakan atau dimanfaatkan oleh manusia. Sumber Informasi tersebut terdiri dari wahyu dari Allah SWT berupa Al-Qur'an dan AlHadist yang berasal dari Nabi Muhammad SAW yang merupakan penjelasan dari Al-Quran. Kedua sumber ini merupakan dasar informasi yang diyakini benar dan harus dipercaya. AlQuran dan Hadist inilah yang menjadi sumber utama tentang kajian informasi dalam Islam. Selain itu, sumber informasi berasal dari ulama dan ilmuwan terbagi menjadi dua aspek. Aspek pertama adalah ide atau gagasan. Ide dan gagasan dari manusia dapat diolah menjadi informasi. Aspek kedua adalah pendapat atau opini juga dapat diolah menjadi informasi, yang menghasilkan scientific information.

Peristiwa atau realitas yang telah menjadi sejarah juga dapat dijadikan sumber informasi. Peristiwa adalah kejadian yang telah diceritakan atau diberitakan dalam kehidupan sosial, dan hal tersebut dapat diolah atau diproduksi menjadi informasi. Sumber-sumber informasi tersebut tersusun dalam satu sistem yang saling terkait dalam membentuk dan menghasilkan suatu informasi yang dapat bermanfaat untuk melakukan ibadah dan perkembangan ilmu dan pengetahuan. Sistem informasi manajemen merupakan hasil dari sumber-sumber informasi tersebut terutama dari ilmuwan yang berasal dari ide dan gagasan yang menghasilkan scientific information.

\section{TINJAUAN PUSTAKA}

Ruang lingkup sistem informasi manajemen tertuang pada tiga kata pembentuknya, yaitu "Sistem, Informasi dan Manajemen". Berikut ini dijelaskan masing-masing makna dari ketiga kata sistem informasi manajemen.

\section{a) Sistem}

Sistem adalah seperangkat komponen yang saling berhubungan dan saling bekerja sama untuk mencapai beberapa tujuan. Selain itu pengertian yang lain sistem terdiri dari unsur-unsur dan masukan (input), pengolahan (processing), serta keluaran (output).

Dengan demikian, secara sederhana sistem dapat diartikan sebagai kumpulan atau himpunan dari unsur atau variabel-variabel yang terorganisasi, saling berinteraksi dan saling bergantung satu sama lain. Sistem di desain untuk memperbaiki atau meningkatkan pemprosesan informasi.

Setelah dirancang, sistem diperkenalkan dan diterapkan ke dalam organisasi penggunanya. Jika sistem yang diterapkan itu digunakan maka implementasi sistem dapat dikatakan berhasil. Sedangkan jika para penggunanya menolak sistem yang diterapkan, maka sistem itu dapat digolongkan gagal.

\section{b) Informasi}

Informasi adalah data yang telah diolah menjadi sebuah bentuk yang berarti bagi penerimanya dan bermanfaat dalam mengambil keputusan saat ini atau mendatang. Sedangkan Mc Leod (2001) mengatakan bahwa "Informasi adalah data yang telah diproses, atau data yang memiliki arti. Informasi juga merupakan salah satu sumber data yang tersedia bagi menejer dan dapat dikelola seperti halnya sumber daya yang lain". Berdasarkan berbagai definisi tersebut 
disimpulkan bahwa informasi adalah data yang diolah dan berguna bagi pemakainya dalam pengambilan keputusan. Informasi yang baik adalah informasi yang memberikan nilai tambah (value added) bagi pemakainya. Pemakai akan menggunakan informasi untuk perencanaan, koordinasi, evaluasi dan pengambilan keputusan. Oleh karena itu informasi harus mempunyai ciri-ciri, yaitu dapat mengurangi ketidakpastian, dapat menggambarkan adanya berbagai peluang dan dapat mengevaluasi hasil.

\section{c) Manajemen}

Manajemen syariah adalah proses perencanaan, pengorganisasian, memimpin, mengendalikan upaya anggota organisasi, dan menggunakan semua sumber daya organisasi lainnya berdasarkan Al Quran dan Hadist untuk mendapat ridho Allah SWT dengan mentalitas sifat Rasulullah SAW yang terdiri dari siddiq, amanah, fathonah dan tabliq. Dengan demikian manajemen syariah melakukan pengelolaan dan mengatur untuk mencapai hasil optimal yang bermuara pada pencarian ridho Allah SWT. Dengan demikian maka setiap langkah yang diambil didasarkan pada aturan-aturan Al Quran dan Hadist.

Sedangkan definisi manajemen konvensional adalah proses sosial yang berbeda yang terdiri dari perencanaan, pengorganisasian, mengarahkan, memotivasi, koordinasi dan pengendalian, diterapkan pada upaya karyawan untuk memanfaatkan secara untuk mencapai tujuan yang telah ditentukan. Ini meliputi proses mendapatkan kegiatan yang diselesaikan secara efisien dan efektif dengan dan melalui orang lain melalui perencanaan, pengorganisasian, kepegawaian, mengarahkan, koordinasi, pelaporan dan penganggaran.

Dengan demikian, pengertian manajemen syariah berbeda dengan manajemen konvensional terutama pada landasan yaitu pada manajemen syariah berlandasarkan pada Al Quran dan Hadist untuk mendapat ridho Allah SWT sedangkan manajemen konvensional berdasarkan pada pola pikir manusia untuk mencapai keuntungan dunia. Berikut ini dijelaskan perbedaan manajemen syariah dan konvensional

Tabel 1. Perbedaan Manajemen Syariah dan Manajemen Konvensional

\begin{tabular}{|c|c|c|}
\hline No & Manajemen Syariah & Manajemen Konvensional \\
\hline 1. & Berlandaskan Al-Qur'an dan Hadist & $\begin{array}{l}\text { Berlandasakan teori buatan manusia dan } \\
\text { etika sekuler }\end{array}$ \\
\hline 2. & $\begin{array}{l}\text { Aktivitas dalam rangka ibadah kepada Allah } \\
\text { SWT }\end{array}$ & $\begin{array}{l}\text { Aktivitas dalam rangka bekerja untuk } \\
\text { dunia }\end{array}$ \\
\hline 3. & Mengikuti etika \& prinsip-prinsip Islam & $\begin{array}{l}\text { Mengikuti aturan dan filosofi sekularisme } \\
\text { dan kapitalisme }\end{array}$ \\
\hline 4. & $\begin{array}{l}\text { Mencapai tujuan organisasi melalui metode } \\
\text { dan prosedur yang }\end{array}$ & $\begin{array}{l}\text { Mencapai tujuan organisasi melalui cara } \\
\text { apa pun yang sesuai keinginan dan ambisi }\end{array}$ \\
\hline 5. & Untuk mencapai ketaatan kepada Allah & $\begin{array}{l}\text { Untuk mencapai kepuasan pemilik dengan } \\
\text { memaksimalkan }\end{array}$ \\
\hline 6. & Berorientasi dan mencapai keselamatan akhirat & $\begin{array}{l}\text { Berorientasi dan mencapai keuntungan } \\
\text { duniawi }\end{array}$ \\
\hline 7. & $\begin{array}{l}\text { Menjaga keseimbangan antara dunia dan } \\
\text { akhirat }\end{array}$ & $\begin{array}{l}\text { Tidak ada menjaga keseimbangan dunia } \\
\text { dan akhirat }\end{array}$ \\
\hline 8. & $\begin{array}{l}\text { Keterampilan teknis (Manajerial) dan ibadah } \\
\text { sangat penting. }\end{array}$ & $\begin{array}{l}\text { Hanya keterampilan teknis (Manajerial) } \\
\text { yang diperlukan }\end{array}$ \\
\hline
\end{tabular}


Ada banyak penelitian mengenai pendekatan, teknik dan teknologi untuk desain dan pengembangan SIM. Namun, ada beberapa artikel yang meliputi dampaknya Sistem Informasi Manajemen mengenai strategi perencanaan dan pengambilan keputusan. Sementara tidak ada definisi sistem informasi manajemen yang diterima secara universal dan yang ada dalam literatur hanya pendapat para peneliti (Adeoti-Adekeye, 1997).

Untuk dapat memahami arti Sistem Informasi Manajemen (SIM) berikut ini disajikan pengertian sistem informasi manajemen dari beberapa pendapat yaitu :

Menurut penulis pengertian sistem informasi manajemen adalah proses pengolahan data menjadi suatu informasi yang benar dan tepat untuk dapat digunakan dalam pengambilan keputusan.

Lee (2001) mendefinisikan sistem informasi manajemen sebagai sistem atau proses yang menyediakan informasi yang dibutuhkan untuk mengelola organisasi efektif. Baskerville dan Myers (2002) secara luas mendefinisikan system informasi manajemen sebagai pengembangan, penggunaan dan penerapan sistem informasi oleh individu, organisasi dan masyarakat. Laudon dan Laudon (2003) mendefinisikan sistem informasi manajemen sebagai studi tentang sistem informasi yang berfokus pada penggunaannya dalam bisnis dan manajemen.

Becta (2005) menggambarkan sebuah sistem informasi sebagai sebuah sistem terdiri dari jaringan semua saluran komunikasi yang digunakan dalam organisasi.

Robert G. Murdick dan Joel E. Ross (1994) dalam bukunya "Information System for Modern
Management" mendefinisikan SIM sebagai:

proses komunikasi dimana

informasi masukan (input) direkam, disimpan dan diperoleh kembali (diproses) bagi keputusan (out put) mengenai perencanaan, pengorganisasian dan pengawasan.

Menurut Joseph F. Kelly (1970) dalam bukunya Computerized Management Information System, SIM adalah:

Perpaduan sumber manusia dan sumber yang berlandaskan komputer yang menghasilkan kumpulan penyimpanan, perolehan kembali, komunikasi dan penggunaan data untuk tujuan operasi manajemen yang efisien dan bagi perencanaan bisinis.

Dalam pada itu Gordon B. Davis (2002) menyatakan tidak adanya kesepakatan di antara para ahli mengenai istilah Management Information System itu. Diantara para penulis ada yang menggunakan information processing system, "information/decision system, atau lebih sederhana lagi information system.

Meskipun demikian, Gordon B. Davis menggunakan istilah Management Information System, mendefinisikan sebagai:

sistem manusia/mesin yang terpadukan untuk menyajikan informasi guna mendukung fungsi operasi, manajemen dan pengmbilan keputusan dalam suatu organisasi.

("an integrated, man/mechine system for providing information to support operations, management and decision making functions in an organization"). 


\section{PEMBAHASAN}

Banyak pengertian sistem informasi manajemen dalam literatur menurut sudut pandang konvensional. Walaupun demikian pengertian sistem informasi manajemen berdasarkan syariah pengertian sistem informasi manajemen adalah proses pengolahan data menjadi suatu informasi yang benar dan jujur berdasarkan Al Quran dan Hadist untuk dapat digunakan membuat perencanaan dan pengambilan keputusan.
Terdapat perbedaan sistem informasi manajemen berdasarkan syariah dengan konvensional. Perbedaan ini terutama pada rujukan dan dasar dalam mencari sumber informasi yaitu Al Quran dan Sunnah. sedangkan sistem informasi manajemen konvensional memcari rujukan pada para ahli dan pakar dibidangnya yang semuannya berdasarkan akal fikiran mereka. Secara lengkap berikut ini disajikan perbedaan sistem informasi syariah dengan konvensional.

\section{Tabel 2. Perbedaan Sistem Informasi Manajemen Syariah dan Konvensioanal}

\begin{tabular}{clcc}
\hline No & Keterangan & Syariah & \multicolumn{2}{c}{ Konvensional } \\
\hline 1 & Rujukan dan dasar hukum AlQuran dan Sunnah & Ya & Tidak \\
\hline 2 & Informasi untuk kepentingan dunia dan akhirat & Ya & Relatif \\
\hline 3 & Jaminan informasi jujur & Ya & Relatif \\
\hline 4 & Jaminan sumber data yang benar & Ya & Relatif \\
\hline 5 & Informasi untuk kepentingan dan kebaikan bersama & Ya & Relatif \\
\hline 6 & Transparansi & Relatif & Relatif \\
\hline 7 & Penggunaan Teknologi Informasi & Ya & Ya \\
\hline 8 & Informasi untuk kepentingan pihak tertentu & Tidak & Relatif \\
\hline 9 & Kehati-hatian dan ketelitian dalam proses pengolahan data & Ya & Ya \\
\hline 10 & Informasi tidak menimbulkan fitnah dan merugikan pihak tertentu & Ya & Ya \\
\hline 11 & Informasi untuk perencanaan dan pengambilan keputusan & Ya & Ya \\
\hline
\end{tabular}

Secara spesifik, al Qur'an menggambarkan bahwa peranan informasi yang hak atau benar, memiliki karateristik sebagai berikut :

(a) Informasi dapat menyenangkan hati penerima informasi. Sesuai dengan Q.S. 11 ayat 120. Allah Taala berfirman :

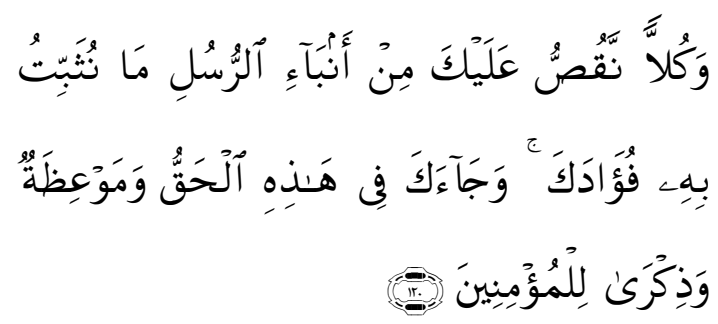

120. dan semua kisah dari Rasul-rasul Kami ceritakan kepadamu, ialah kisah-kisah yang dengannya Kami teguhkan hatimu; dan dalam surat ini telah datang kepadamu kebenaran serta pengajaran dan peringatan bagi orang-orang yang beriman.

(b) Informasi yang benar dan perlu diketahui oleh orang lain dan tidak mencampur adukkan berita yang benar dengan berita yang salah/batil ( lihat Q.S. 2.42).

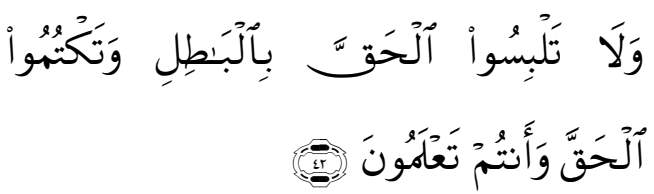

42. dan janganlah kamu campur adukkan yang hak dengan yang bathil dan janganlah kamu sembunyikan yang hak itu, sedang kamu mengetahui.

(c) Informasi yang adil dengan tidak memihak salah satu pihak. Allah Taala berfirman dalam surat (lihat Q.S. 49:9).

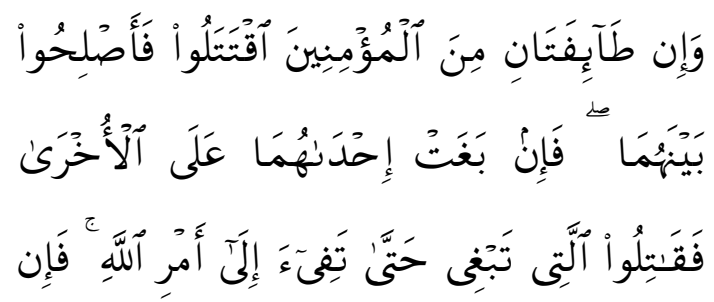




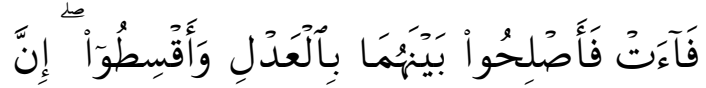

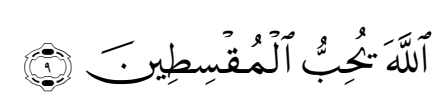

9. dan kalau ada dua golongan dari mereka yang beriman itu berperang hendaklah kamu damaikan antara keduanya! tapi kalau yang satu melanggar Perjanjian terhadap yang lain, hendaklah yang melanggar Perjanjian itu kamu perangi sampai surut kembali pada perintah Allah. kalau Dia telah surut, damaikanlah antara keduanya menurut keadilan, dan hendaklah kamu Berlaku adil; Sesungguhnya Allah mencintai orangorang yang Berlaku adil.

(d) Informasi yang dapat menyelesaikan

perbedaan/pertentangan diantara penerima dan dapat mendamaikan dari perselisihan mereka (lihat Q.S. 2:213).

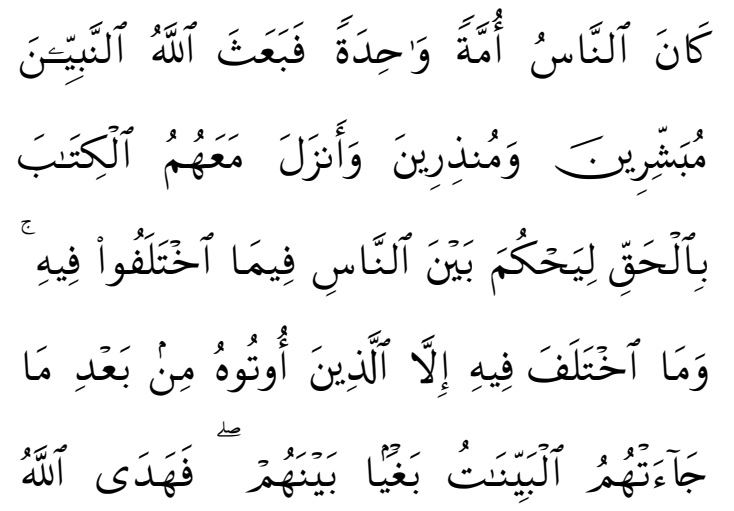

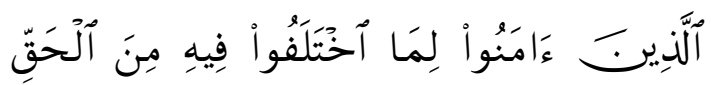

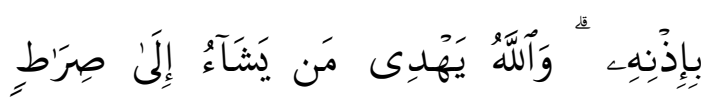

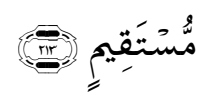

213. manusia itu adalah umat yang satu. (setelah timbul perselisihan), Maka Allah mengutus Para Nabi, sebagai pemberi peringatan, dan Allah menurunkan bersama mereka kitab yang benar, untuk memberi keputusan di antara manusia tentang perkara yang mereka perselisihkan. tidaklah berselisih tentang kitab itu melainkan orang yang telah didatangkan kepada mereka Kitab, Yaitu setelah datang kepada mereka keterangan-keterangan yang nyata, karena dengki antara mereka sendiri. Maka Allah memberi petunjuk orang-orang yang beriman kepada kebenaran tentang hal yang mereka perselisihkann itu dengan kehendak-Nya. dan Allah selalu memberi petunjuk orang yang dikehendaki-Nya kepada jalan yang lurus.

(e) Informasi yang tidak hanya mengikuti kepuasan subjektif. Penyampaian informasi yang cendrung tidak sesuai dengan kebenaran, tetapi informasi yang mendorong munculnya semangat berkompetisi dalam berbuat kebaikan (sabiqun bil al kahiraat) serat dapat menyentuh rasa penerima informasi, sehingga mereka memiliki ketetapan hati tentang kebenaran yang diterimanya (lihat Q.S. 5:48 dan 83 ).

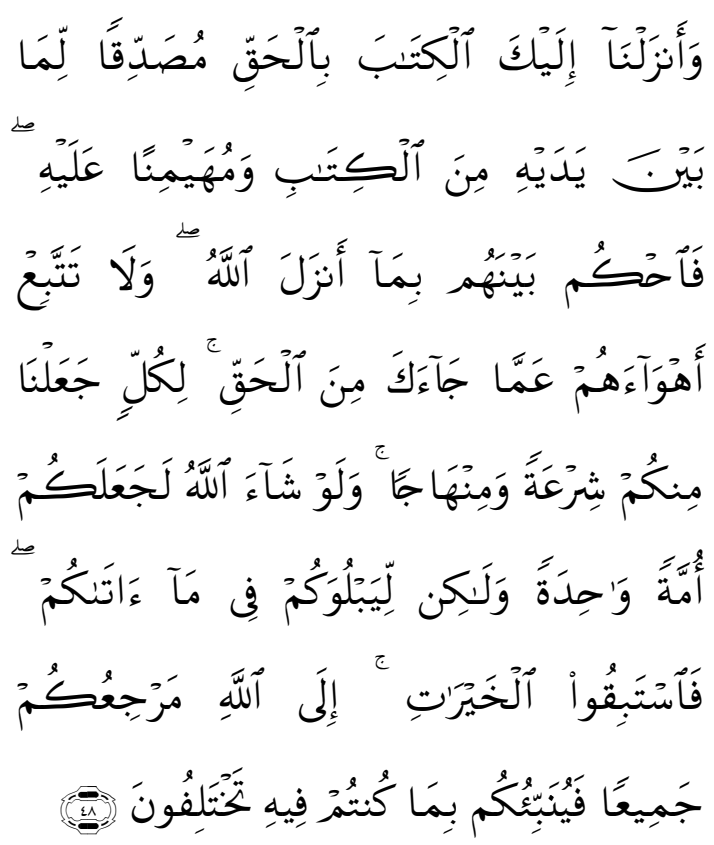

48. dan Kami telah turunkan kepadamu Al Quran dengan membawa kebenaran, membenarkan apa yang sebelumnya, Yaitu Kitab-Kitab (yang diturunkan sebelumnya) dan batu ujian terhadap Kitab-Kitab yang lain itu; Maka putuskanlah perkara mereka menurut apa yang Allah turunkan dan janganlah kamu mengikuti hawa nafsu mereka dengan meninggalkan kebenaran yang telah datang kepadamu. untuk tiap-tiap umat diantara kamu, Kami berikan aturan dan jalan yang terang. Sekiranya Allah menghendaki, niscaya kamu dijadikan-Nya satu umat (saja), tetapi Allah hendak menguji kamu terhadap pemberian-Nya kepadamu, Maka berlomba-lombalah berbuat kebajikan. hanya kepada Allah-lah kembali kamu 
semuanya, lalu diberitahukan-Nya kepadamu apa yang telah kamu perselisihkan itu,

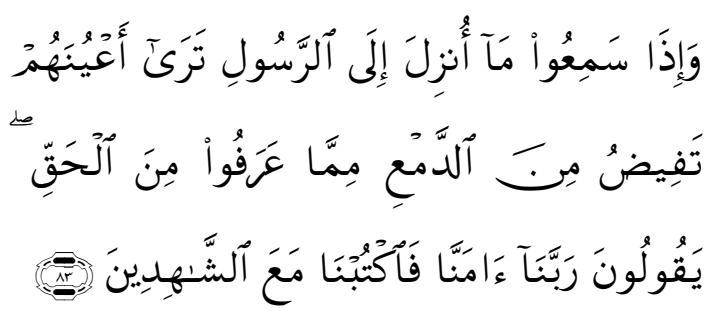

83. dan apabila mereka mendengarkan apa yang diturunkan kepada Rasul (Muhammad), kamu Lihat mata mereka mencucurkan air mata disebabkan kebenaran (Al Quran) yang telah mereka ketahui (dari Kitab-Kitab mereka sendiri); seraya berkata: "Ya Tuhan Kami, Kami telah beriman, Maka catatlah Kami bersama orang-orang yang menjadi saksi (atas kebenaran Al Quran dan kenabian Muhammad s.a.w.).

\section{KESIMPULAN}

Dalam perspektif Islam terdapat sumber informasi yang selalu digunakan atau dimanfaatkan oleh manusia. Sumber Informasi tersebut terdiri dari wahyu dari Allah SWT berupa Al Qur'an dan AlHadits yang berasal dari nabi Muhammad SAW yang merupakan penjelasan dari Al Quran. Banyak pendapat para ahli pengertian sistem informasi manajemen secara konvensional. Namun berdasarkan prespektif Islam pengertian sistem informasi manajemen adalah proses pengolahan data menjadi suatu informasi yang benar dan jujur berdasarkan Al Quran dan Hadist untuk dapat digunakan membuat perencanaan dan pengambilan keputusan. Terdapat perbedaan sistem informasi manajemen berdasarkan syariah dengan konvensional. Perbedaan ini terutama pada rujukan dan dasar dalam mencari sumber informasi yaitu Al Quran dan Sunnah. sedangkan sistem informasi manajemen konvensional memcari rujukan pada para ahli dan pakar dibidangnya yang semuannya berdasarkan akal fikiran mereka.

Al-Qur'an menggambarkan bahwa peranan informasi yang hak atau benar, memiliki karateristik Informasi dapat menyenangkan hati penerima informasi, Informasi yang benar dan perlu diketahui oleh orang lain dan tidak mencampur adukkan berita yang benar dengan berita yang salah/batil, Informasi yang adil dengan tidak memihak salah satu pihak, Informasi yang dapat menyelesaikan perbedaan atau pertentangan di antara penerima dan dapat mendamaikan dari perselisihan mereka dan Informasi yang tidak hanya mengikuti kepuasan subjektif.

\section{DAFTAR PUSTAKA}

Adeoti-Adekeye. 1997. The importance of management information systems. MCB Bank. Library Review, 46 (5), 318-327.

Baskerville, R.L. and Myers, M.D., 2002. Information Systems as a Reference Discipline. MIS Quarterly, 26 (1), 1-14.

Becta (2005). School Management Information Systems and Value for Money. Coventry: Becta. [Online] Available: http://www.egovmonitor.com/re ports/rep12009.pdf .

Davis, Gordon B Davis. 2001. Management Information Systems : conceptual Foundation Structure and Development. PT Prenhalindo. Jakarta.

Joseph F. Kelly. 1970. Computerized Management Information System, Macmillan. New York.

Laudon, K.C. dan Laudon, J.P. 2003. Management Information Systems: Managing the Digital Firm (Upper Saddle River, NJ: Prentice Hall).

Lee, A.S., 2001. Editorial. MIS Quarterly, 25(1), iii-vii.

McLeod, Raymond. 2001. Sistem Informasi Manajemen Jilid 2 Edisi ke 7. Prenhallindo. Jakarta. 
2018, Jurnal Tabarru' : Islamic Banking and Finance 1 (1) : 63 - 70

Murdick, R.G., Ross, J.E, dan Clagget, J.R. 1987. Information Systems for Modern Management. (third ed.). Prentice Hall of India. New Delhi.

Scott, G.M. 2004. Prinsip-prinsip Sistem Informasi Manajemen (terjemahan). PT RajaGrafindo Persada. Jakarta 